\title{
A rhizomatic case analysis of instructional coaching as becoming
}

by Brandon Sherman, Indiana University-Purdue University Indianapolis, Mari Haneda, Pennsylvania State University, \& Annela Teemant, Indiana University-Purdue University Indianapolis

\section{Introduction}

Instructional coaching has become recognized as having more impact on teacher professional development (PD) than traditional "one-and-done" teacher workshops, particularly in U.S. K-12 settings (e.g., Aguilar, 2013; Knight, 2007). Much of the research on coaching to date has focused on establishing this impact (Kraft, Blazar, \& Hogan, 2018), often measured by gains/losses in students' achievement scores on standardized tests (e.g. Elish-Piper \& L'Allier, 2011; Shidler, 2009). Other research has focused on the dynamics of coaching support and interaction (e.g. Coburn \& Woulfin, 2012; Rainville \& Jones, 2008). As valuable as this work has been, there remains a need to develop a greater theoretical understanding of instructional coaching as a force for change within the complex web of classrooms and schools, to say nothing of students' and teachers' lives. In this chapter, drawing on the work of Gilles Deleuze (1925-1995) and Félix Guattari (1930-1992), particularly A Thousand Plateaus: Capitalism and Schizophrenia (1987), we argue for an alternative conception of one-on-one instructional coaching, seeing it as a space of becoming, in which coach and teacher are free to explore and experiment with pedagogical ideas. The data we present are derived from analyses of

This is the author's manuscript of the article published in final edited form as:

Sherman, B., Haneda, M., \& Teemant, A. (2020). A Rhizomatic Case Analysis of Instructional Coaching as Becoming. In Transforming Language and Literacy Education (pp. 104-119). Routledge. https://doi.org/10.4324/9780429491702-6 
episodes of coach-teacher conference conversations, drawn from a U.S.-based PD program (see Teemant, 2014).

The PD and instructional coaching explored here are built on critical sociocultural perspectives on education (Vossoughi \& Gutiérrez, 2016). While this body of theory can be seen as establishing goals for transformative practices, we believe that concepts derived from rhizomatic thinking (Deleuze \& Guattari, 1987) can also provide theoretical tools to understand the potentialities and the processes of transformation involved in PD and coaching conversations.

Deleuze and Guattari (1987) describe traditional linear Western conceptualizations of knowing, such as linguistic sentence diagrams, as arborescent thinking (p. 5). Using the figuration of rhizomes, they propose an alternative way of thinking - rhizomatic thinking, or knowing as a process and a "present-becoming" (Deleuze \& Parnet, 1987, p. 23). According to Deleuze and Guattari (1987):

A rhizome has no beginning or end; it is always in the middle, in between things, interbeing, intermezzo. The tree is filiation, but the rhizome is alliance. The tree imposes the verb "to be", but the fabric of the rhizome is the conjunction "and ... and ...and." This conjunction carries enough force to shake and uproot the verb "to be". (p. 25, italics in the original)

While rhizomes have been referred to as a metaphor (e.g., Mackness, Bell, \& Funes, 2016), Deleuze and Guattari (1987) themselves seemed to be against this. Hagood (2004) treats the rhizome as a figuration. She notes similarities between figurations and 
metaphors but draws an important distinction in that figurations draw on the complexity of a phenomenon in order to aid in understanding it as becoming. This stands in contrast to metaphors, which are used to determine or define a phenomenon through description. We can consider the rhizome as a way of thinking.

Thinking rhizomatically means pursuing the interminable "and" through the multitudes of connections and encounters that stimulate new thinking and acting. This allows us to consider PD events, including the interactions that occur in coach-teacher conferences, as "assemblages," ecologies of complex and interrelated material and discursive elements that can produce surprising outcomes (e.g., Leander \& Wells Rowe, 2006; Strom \& Martin, 2017). Deleuze and Guattari held assemblages to be composed of "objects, bodies, expressions, qualities, and territories" (Livesey, 2010, p. 18). As shorthand for this, we have chosen the term "element", as has been used by Strom and Martin (2017), which is meant to convey agential parity between animate objects (which might otherwise be called actors) and inanimate, intangible, and/or discursive objects. Other terms that have been employed to this effect are components (Barad, 2007) and actants (Latour, 2017).

Any change in an element can have unexpected consequences for the entire assemblage and beyond. This fluidity is rooted in an ontology of becoming that underscores Deleuze and Guattari's work (Stagoll, 2010). A focus on becoming, as opposed to being, emphasizes a world that is ever-shifting, never-complete, always in motion. A state (being) can be nominalized or thingified, but a process (becoming) remains as a verb. 
Additionally, the concept of becoming helps shift from thinking of the world as consisting of isolated individuals and objects with inherent properties. Instead, heterogeneous elements come together into temporary and shifting alliances, or assemblages (Strom \& Martin, 2017, p. 8). Thus, we understand instructional coaching not as an intervention, but rather as a space of becoming (Deleuze and Guattari, 1987, p. 272). This allows for the emergence of unexpected and powerful transformations, not only in teacher practices and students' learning, but potentially in teacher and student identities and in classroom dynamics.

On this premise, in this chapter, we examine coaching interactions between Sabrina, an instructional coach, and Sharon, a fifth-grade teacher (pseudonyms). Instead of focusing on a moment-by-moment analysis of fissures in an assemblage (Leander \& Wells Rowe, 2006), drawing on key rhizomatic concepts, we examine coaching activities across events: how happenings in coaching conference (our focus) become extended and intertwined, and how progressively larger assemblages of Sharon's classroom and her students' school world occurred. In the next section, we define the key concepts that we use: assemblage, rhizomatic lines, and territorialization. Our aim is to show how rhizomatic ruptures or fissures that emerge in practice may open up new possibilities for the teacher and students.

\section{Key concepts}

\section{Assemblage}


As a good entry point for thinking rhizomatically, we begin with the concept of "assemblage". Deleuze and Guattari used the French term agencement, usually translated as "arrangement," "putting together" or "laying out" (DeLanda, 2016). Agencement, as used by Deleuze and Guattari (1987), is commonly translated in English as "assemblage," which is an approximation at best. For this reason, there are a number of points to bear in mind when thinking with this concept. First, what is emphasized is not the arrangement itself but the process of arranging, organizing, and fitting together. An assemblage is an ongoing process of becoming through arranging, organizing or congealing heterogeneous elements. Second, it is not a set of predetermined parts that are subsequently pieced together to construct a pre-conceived structure, but rather a spontaneous relation of heterogeneous elements that envelop or "stake out" a territory (Deleuze \& Guattari, 1987, p. 503). Third, it is not the product of an outside actor since it can shift and transform on its own through the dynamic interplay of various elements. Based on this understanding, we consider an assemblage to be an ensemble of elements, human and non-human, that "function collectively in a contextually unique manner to produce something (e.g., teaching practice, a situated identity)" (Strom \& Martin, 2017, p. 7). Non-humans can take a variety of forms: concrete (a desk, a light), material (sounds, smells), discursive (ways of address, languages used), or abstract (ideas, protocols). Deleuze and Guattari (1987) note that assemblages are simultaneously semiotic and pragmatic, operating both in terms of enunciation and action, or "what is said and what is done" (p. 504).

Viewed from this perspective, a classroom can be considered as an assemblage, "composed of humans, writing implements, writing surfaces, texts, desks, doors, as well 
as disciplinary forces whose power and agency are elicited through various routines (e.g., singing the anthem) and references ('In algebra, we always do this...')" (Strom \& Martin, 2017, p. 7). This allows teaching and learning to be understood as co-produced by classroom assemblages, with each element in the assemblage being recognized as an active agent in this joint production. Further, assemblages can share elements with other assemblages, and occur within larger assemblages. For example, a classroom assemblage may consist of smaller assemblages, such as pair or group work, and at the same time act as one element in the larger assemblage of the school. What is particularly relevant for this chapter is the emergent, indeterminate nature of an assemblage and the relational cofunctioning of all the elements, both human and non-human, within it.

\section{Territories and lines}

Rhizomes consist of a multiplicity of lines operating within a shifting territory, forming contours, connections, and breaks. By means of these lines, assemblages shift and reconfigure, potentially extending in any direction to form new assemblages. The dynamics of these changing assemblages (or lack thereof) result from the interplay of two types of lines: molar, and molecular, the latter of which has potential to become lines of flight (Deleuze \& Guattari, 1987). In relation to teaching, rigid molar lines include curriculum standards, bell schedules, codes of conduct, and normative assumptions about what constitutes a good student; these "encapsulate the presently accepted norms, rules, social structures, and forms of communication" (Strom \& Martin, 2017, p. 9). They are territorializing (or boundary enforcing) forces against which behavior and conditions (e.g. classroom organization) can be constantly checked. On the other hand, supple molecular 
lines are micropolitical; they carry out the day-to-day work of the molar norm. In teaching, molecular actions may involve teachers' implementing curriculum standards in their classrooms and observing various institutional norms, both academic and social. According to Strom and Martin (2017), "the individual thoughts, actions, and practices of teachers that feed into and reinforce the molar system are the molecular lines at work" (p. 9). However, molecular lines can also become lines of flight, lines that have the potential to transform a territory by bringing about new and unexpected arrangements and relationships both within and outside of it. As Boldt (2017) explains, in deterritorialization, "there is a breakdown of known patterns, expectations, norms, and authorities, and the production of new... desires" (p. 183). In classroom practice, for example, this may happen when teachers respond contingently to students' unexpected answers, not following the expected learning path and potentially moving to new, exciting engagement with students about the topic at issue. In and of themselves, lines of flight are neither good nor bad. They have potential for both creativity and destruction. The same can be said of territorialization and deterritiorialization, both of which can be beneficial or detrimental, often at the same time. It so happens that, in this chapter, we approach these concepts in relation to one teacher's application of Six Standards Pedagogy. Thus, here, it is the creative potential of lines of flight on which we focus.

\section{The Six Standards Pedagogy}

The Six Standards Pedagogy (Teemant, 2018), which is the basis of the coaching approach examined here, is informed by critical sociocultural theory (Lewis, Enciso, \& Moje, 2007; Vossoughi \& Gutierrez, 2016). The term, standards, is not used in the sense 
of a curriculum standard, but should be understood as a set of key pedagogical principles guiding practice. Five of the principles, derived from the "five standards for effective pedagogy" (Tharp, Estrada, Dalton, \& Yamauchi, 2000), are grounded in sociocultural theories of learning and formulated on the basis of cumulative research-based evidence for effective teaching practice for multilingual students. The five pedagogical principles include Joint Productive Activity, Language and Literacy Development, Contextualization, Challenging Activities, and Instructional Conversation (IC). Particularly important is the principle of IC (Goldenberg, 1992), in which a teacher and a small group of students collaborate in a purposeful dialogic discussion, because it enables the teacher to tailor her or his instruction to the zones of proximal development (Vygotsky, 1978) of the individual students involved - contextualizing learning in relation to students' lived experiences and interests (Contextualization).

Six Standards Pedagogy has an equity orientation, captured by the additional principle of Critical Stance (CS). CS is grounded in critical pedagogical thinking (Freire, 1970/2002; Lewison, Leland, \& Harste, 2014). Permeating and augmenting the other five principles, CS aims to cultivate critical thinking and critical consciousness (Freire, 1970/2002) among students. By enacting CS, teachers are expected to (a) engage students in identifying and reflecting on problematic issues in students' lives or in larger settings, and (b) help them take actions to resolve them in an age-appropriate manner. For example, in the classrooms of past PD participating teachers, young children initiated a recycling initiative in school, conservation awareness campaigns (Haneda, Teemant, \& Sherman, 2017), and an anti-bullying program (Kopp, 2012). As with any other 
pedagogical concept, CS can become a molar line (i.e. a normalizing force). However, in calling for pedagogy that aids students in "interrogating conventional wisdom and practices" (Teemant, Leland, \& Berghof, 2014, p. 140), CS has the potential of creating lines of flight as well.

Following these same research-based pedagogical principles, Six Standard Instructional Coaching is designed to be dialogic in nature. The coach assists development within the teachers' zone of proximal development (Vygotsky, 1978) by helping them to understand, appropriate, and enact Six Standards Pedagogy (Haneda, Sherman, \& Teemant, 2019). In this way, the coaching process involves both sense making, as teachers come to build their own understandings of the principles, and practical application, as coaches support teachers in applying and refining pedagogy based on the principles.

\section{Research methods}

\section{Context}

The data used for this chapter were collected as part of study of Six Standards Instructional Coaching, as carried out in an urban elementary school in the midwestern United States. Our focus is on coach-teacher conference interaction between Sharon and Sabrina. Sharon had 23 years of teaching experience and taught sixth graders. As with other PD participants, Sharon first learned about the six pedagogical principles through a five-day, thirty-hour summer workshop, and then participated in seven cycles of one-onone instructional coaching at intervals throughout one school year. Each cycle consisted 
of a pre-conference, a classroom observation, and a post-conference (conferences averaging about thirty minutes in length). ${ }^{1}$ Sabrina had nine previous years of experience as an elementary English-Spanish bilingual teacher, and at the time of the study had been an instructional coach for over five years.

The demography of Sharon's sixth-grade classroom reflected the school, which was culturally diverse (75\% Hispanic and 16\% African American, with smaller populations of White, Asian, and multiracial students). The school served a poor neighborhood with $95 \%$ of students receiving free/reduced lunch, ${ }^{2}$ a proportion that surpassed both the national average (42\%) and the state average (36.1\%) (NCES, 2012). Because of low performance scores, the school district had adopted a prescriptive curriculum that specified the what and why of teaching, resulting in a teaching environment that some teachers found constrictive (Haneda, Teemant, \& Sherman, 2017).

\section{Data collection and analysis}

Our primary sources of data were video and audio recordings of the Sabrina-Sharon coaching conferences, collected throughout the seven cycles of coaching. Other sources of data consulted were the coach's notes, audio recordings of three classroom events, and the exit interview with Sharon. Classroom observation data, collected by Sabrina, provided some insight into changes in Sharon's classroom over time. We, the authors, first viewed all the video-recorded conference interactions. Then, using Studiocode video analysis software, we extracted episodes related to Critical Stance (CS) and Instructional 
Conversation (IC) for analysis, as these pedagogical principles were our analytical focus in a larger study.

In this chapter, we follow the lead (if not the method) of Hofsess and Sonenberg (2013), who returned to data they had previously analyzed through conventional qualitative methods in order to "re-vision" it rhizomatically. We, too, have returned to CS-IC related segments of video-recorded data, but are viewing it anew through a rhizomatic lens. Though a number of scholars have drawn on rhizomatics to analyze empirical data (e.g. de Freitas, 2012; Leander \& Wells Rowe, 2006), there is not, and likely could not be, an established protocol for doing so. Rather, it is the work of the authors (and, to some extent, of the readers) to engage with rhizomatic concepts and apply them to the work of analysis. Further, while many of the cited examples of rhizomatic research focus on relatively short time scales, our analysis spans a school year, allowing us to consider how assemblages shift over time (also see Kuby, 2017). The following rhizomatic analysis aims to illuminate how the changes we observed in the instructional coaching assemblage had ramifications for the larger classroom assemblage and beyond.

\section{Findings}

\section{The coaching assemblage}

Recall that an assemblage is defined by the involvement of its elements in the production of something, in this case Sharon's becoming, along with the becoming of Sabrina, the classroom, the conferences, the students, and a multiplicity of others. From the assemblage of a coaching conference, its influences can be mapped into the larger 
assemblages of Sharon's classroom and, to some extent, of the school. The assemblage(s) represented by the conferences is at once singular and multiple, inasmuch as each conference can be seen as its own separate assemblage, and at the same time the seven cycles of conferences can be viewed as a single evolving assemblage. It is in relation to this latter frame that the following description is provided. Below, some of the elements constituting conferences, human, material, and intangible, are described in order to show the complexity and nuance that emerge when thinking about the conferences rhizomatically. Our goal is not to present an exhaustive list nor to trace direct causal relationships, but rather to call attention to the value of seeing the conferences as an assemblage.

Sabrina was an outsider, in that she was neither employed by the school district, nor was she from the area. As an external coaching consultant funded by a federal government's grant, Sabrina's official role was to support Sharon's learning. Instead of being authoritative, she took a more "responsive" approach by valuing a dialogue about Sharon's classroom and her pedagogical goals. To this end, she used a variety of interactional strategies such as posing questions, and offering suggestions. Sharon was not a passive participant in this process. She offered her own interpretation of classroom events, her students, and her teaching; co-planned lessons and activities with Sabrina; evaluated the observed lessons; and responded to the suggestions Sabrina introduced, either agreeing with or pushing back against them. 
In each conference, the two sat in a school office space (not always the same space), sometimes alone in the room, sometimes sharing it with others, as the business of the school day unfolded around them and occasionally intruded. In several instances, for example, loud announcements from the school's PA system put the conference on hold. The ringing of bells marked the regimented schedule of the day. Some conferences were conducted across a table, with documents and activity materials in sight and referenced, while in others Sabrina and Sharon sat across from each other in chairs with no intervening furniture or documents. Other intangible elements, such as the temperature, time of year, weather, and time of day, were occasionally referenced in conversation. A video camera and an audio recording device were used in each conference.

While varying in terms of the specific content under discussion, as noted earlier, each conference cycle involved a pre-conference, classroom observation, and a postconference. The pre-conference generally focused on planning and preparing for the class to be observed. At times, Sharon's progress with regard to previously co-established pedagogical goals (e.g. the use of independent small group activities) would be discussed. The post-conference, following the classroom observation, focused on interpreting and co-evaluating the observed activities, as well as considering goals for the immediate and long-term future. In this way, the goals, as jointly negotiated products of coach and teacher, were enduring elements in the conference assemblage that kept being re-shaped. These long- and short-term goals bridged the conferences across time and conference dialogue. 
In both tangible and intangible ways, the key pedagogical principles of the Six Standards were important elements in the conference, often acting as molar lines. Materially, the principles were present in the form of official textual representations printed on sheets of paper that were referred to by both Sharon and Sabrina, helping them shape and direct the course of conversation. Intangibly, they were present as abstract ideas and terminology, previously encountered by Sharon in the workshop and introduced into the coaching conversation so that Sharon could develop a deeper level of understanding to enact them in her classroom.

Taken together, these elements all functioned together to bring about changes in Sharon's professional practice over the course of the semester. Discussions in conferences, along with Sabrina's classroom observation notes, evidenced a consistent increase in Sharon's satisfaction with the results of her instruction in terms of student engagement, language use, and higher order thinking. What follows is a closer look at one example of changing dynamics rippling outward from the coaching conferences to the classroom and school.

\section{Introducing critical stance}

For the first several months, discussions between Sharon and Sabrina were largely concerned with practical classroom matters such as planning and the implementation of activities, particularly Instructional Conversations (ICs). As a small group conversation where teachers sit with three to five students, guiding dialogue between them through strategic questioning, ICs represent a contrast with the hierarchical teacher-centered whole-class instruction. Though she had already been implementing small group 
activities with her students to some extent, Sharon did not conduct an IC until her third conference cycle. It was in this cycle that Sabrina introduced Critical Stance (CS) into the conversation:

Sabrina: Here's the last [principle] that we want to think about...It's that Critical Stance. Getting them to think about how to transform inequities... So, the Critical Stance, I'm going to poke at you to think about how you want to do the Critical Stance with your kids, and what it will look like in your classroom. What do you think about that?

Sharon: I think it's a good one. I think it's easily done.

Two things are notable in this exchange. First, Sabrina frames CS in terms of thought rather than action (repeatedly using the words "think about"). Second, it should be noted that Sharon's immediate acceptance of the idea contrasted with the experience of other teachers, who had expressed resistance to CS. Some teachers, who were participating in coaching at the same time, did not initially see how to include CS, which called for challenging of norms and conventions in their instruction (see, for example, Haneda, Teemant, \& Sherman, 2017). In contrast, CS, as Sharon understood it at this point, resonated with her preexisting teaching practices and philosophy. Once explicitly introduced, CS seemed to become an important element in the conferences that followed. Conversations came increasingly to revolve around issues of power and equity, with Sharon saying, for example, of one of her lessons, "I wanted to take it one step further to go into civil rights: Why is it important for everyone to get a good education?" With the introduction of CS as an element in the conference assemblage, Sharon and Sabrina's discussion began to shift from practical pedagogical considerations noted earlier towards 
strategies to prompt students to identify and question inequity or problematic issues in their lived worlds. To take one example, in co-planning a lesson on the US civil rights movement, they discussed questioning strategies to encourage students to reflect on their own lives, and to question taken-for-granted assumptions:

Sabrina: I think what you're saying is you really want the kids to understand "how does this affect me?" In terms of civil rights, if civil rights had not happened, how would that affect you right now? Girls in the class, if you could not go to school, what would your life be like? [...]

Sharon: That would be an interesting conversation. If you're a girl, you don't get to go to school, if you're African American or Latino you're not going either. How many kids in your class would get to go to school? This exchange indicates a shift from a focus on instruction to a discussion of the lives of the students and their experiences, particularly where equity and justice were concerned. In this way, it was emblematic of a larger shift in the shape of the conference assemblage. Whereas Sabrina could previously function as an expert in terms of the pedagogy, on the topic of the students' lives Sharon became more of an authority. Further, as Sharon conducted activities enacting CS in her classroom, she came back to the coaching conferences with issues raised by the students themselves. These issues included bullying in school, unfair lunchroom policies, and (to Sharon's distress) the existence of contract killers in the students' community. In this way, CS, once introduced to coaching conversations, became an important element in Sharon's classroom, in turn affecting the coaching conversations. We present one specific case to illustrate this dynamic, as the 
molar lines of state standardized testing became deterritorialized through Sharon's use of pedagogical principles, particularly those of IC and CS.

\section{Interrogating and deterritorializing ISTEP}

Every spring, all $3^{\text {rd }}$ through $8^{\text {th }}$ grade students in Sharon's school were required to take a standardized achievement test known as the Indiana Statewide Testing for Educational Progress (ISTEP) exam. Within the assemblages of the classroom and school, ISTEP was a major element, with students and teachers relating to it exclusively in terms of evaluation and satisfactory achievement scores. Sharon referred to it as "the elephant in the room", a ubiquitous presence that, while discussed, was rarely acknowledged in terms of its influence on the lived experience of the teachers and students (Sharon referred to it as an influence on the content of her curriculum, and also on her time). In the fourth cycle, Sharon described how ISTEP (and other school-wide activities, such as assemblies) disrupted her classroom time and made it difficult for her to maintain the consistent practices she felt were necessary to enable students to progress. In her description, ISTEP acted as a territorializing force, posing challenges for the new Six Standards practices to become established in the classroom.

Seen rhizomatically, coaching conferences worked against the territorializing force of ISTEP in several ways. First, in conference, Sabrina encouraged Sharon to set aside 45 minutes of "non-negotiable time" every day in order to consistently pursue her pedagogical goals rather than spending time preparing for the test, as required by the school. This non-negotiable time represents an active resistance to territorializing forces 
of ISTEP. Further, as Sharon became more comfortable with the Six Standards Pedagogy, she drew on CS, which allowed lines of flight to arise as we describe in what follows.

Later in the school year, having already begun planning lessons around student experiences, Sharon and Sabrina explored the possibility of designing activities to address the role of ISTEP in the students' lives. At first, Sharon represented ISTEP as a force the students could react to, changing their own behaviors in ways that did not conflict with the unquestioned dominant position of the test in the classroom. She discussed how she wanted her students to reflect on how they could change themselves to better prepare for ISTEP through "their own sleep habits and having a pencil sharpened, and those kind of things." In response, Sabrina shifted their focus to interrogating ISTEP itself, suggesting:

You could get some interesting writing with what happens to ISTEP after it leaves the building. (laughter). The whole idea of, where does it go? What do they think about it?

Sharon then began to speculate how this might change the way the students related to the test, suggesting that she wanted her students to have "ownership" of ISTEP, as she noted: "...because they buy into it." In other words, she hoped to create an activity that could shift the students' relation to ISTEP from acceptance (buy-in) to critique. Asked how this might affect her students, Sharon characterized it as reframing her students' perception of the test as "...not this big scary thing someone's doing to me" but something over which they have some ownership. 
To this end, Sharon conducted Instructional Conversations in which her students discussed and questioned ISTEP. After observing these ICs, Sabrina highlighted the surprise that emerged from this conversation:

Sabrina: Those kids, in the group yesterday, thought you loved ISTEP. They thought we loved ISTEP.

Sharon: They did. And they weren't going to tell us otherwise.

Sabrina: And that was very interesting, when they thought about it. You could see that moment of going, oh, she may not love ISTEP.

Sharon: Exactly. And what I thought was courageous of little Kimberly was, really, to share. It wasn't easy for her. I thought that took a lot of courage, because everybody else was like, it wasn't that hard. She was the first to say, well, some of it's hard. (And the rest said, oh yeah) But I thought that took a little bit of courage, to say I have trouble with parts of it.

Through implementation of ICs and CS, Sharon was able to reposition herself in relation to ISTEP, becoming (in the regard of her students) not an enforcer of ISTEP but rather a person to consider separately from it, one who may have her own reservations about the testing. Additionally, the conversation opened up a space for students to name the difficulties they had with the test - another line of flight. The students began to see ISTEP not as an abstract authoritative force, but as a concrete element in the assemblages of their classroom and school. This represented a new perspective for the students to take with regard to ISTEP, with a newfound capacity to push back against it. 
Near the end of the school year, Sharon's students had written poems expressing their feelings about ISTEP (some overtly critical), and Sharon had displayed these in the hallway. She mentioned that other teachers had commented on the poems, saying "They're afraid I was getting into trouble, because it's about ISTEP", as the poems expressed negativity. In other words, her colleagues recognized ISTEP as a molar line in the school that was not to be questioned, and saw the students' critiques (such as they were) as a line of flight that might disrupt the status quo and thus incur territorializing attention from administration. In spite of her colleagues' concerns, Sharon expressed confidence that the display was appropriate and would not have negative repercussions.

Thus, deterritorialization occurred as students came to realize, through discussion, that Sharon was not an active agent of ISTEP, but in fact had her own feelings about it. Further, the students' relationship to ISTEP changed in that they were able to interrogate it by questioning it in ICs (transforming a unidirectional relationship into a bidirectional one) and to express their feelings about it in a public setting through their poems. Finally, this public display quite probably influenced the larger assemblage of the school, as critiquing ISTEP was shown to be possible in terms of what students were both allowed and able to do. It can be argued that this emerged from the assemblage of Sabrina and Sharon's conferences, and specifically from changes brought about as Sharon and the students engage with the principle of CS in their lived world of the school.

\section{Conclusion}


By drawing on the key rhizomatic concepts, we examined how a discussion of the pedagogical principles of Critical Stance (CS) and Instructional Conversation (IC) in the coaching conversation led to a change in practice in Sharon's classroom. Sharon's enactment of CS permitted her students to voice their perceptions of Sharon as a test enforcer, thereby shifting the dynamics of the classroom assemblage. Contingently responding to students' voices, Sharon repositioned herself as an individual who struggled with ISTEP just like her students; this then led her students to express their feelings in poems that were displayed outside of the classroom in public spaces. Thus, currents that emerged during coaching sessions affected what happened in the larger assemblages of the classroom and the school. While our example from Sharon's classroom is limited in scope, we would like to suggest that coaching conversations have the potential to open interstitial spaces to challenge institutional norms, which in turn may change not just isolated pedagogical practices, but the ecology of the classroom as a whole. Further, though only hinted at here, change involves non-human, discursive, and intangible elements such as IC and CS. As shown in this chapter, IC allows students to engage in an academic inquiry-oriented dialogue in which students can voice their opinions, which may lead to creative lines of flight, as shown in the example. The enactment of CS can be used to encourage students' critical thinking, helping them identify ways in which they can act agentively against inequitable practices in their lives. These pedagogical principles can potentially become powerful elements that are capable of acting in and beyond assemblages to recast relationships between constituent elements, such as with the students and ISTEP. 
The inherent aim of instructional coaching and associated professional development (PD) is often held to be that of bringing about positive change in teaching practice that benefit students. While any PD can become a territorializing force if it is implemented in a topdown manner, as we hope to have shown here, instructional coaching conversations embedded in a PD program, such as Six Standards Pedagogy, has the potential of positively impacting the classroom, the school, and even the students' lives in the larger world. 


\section{References}

Aguilar, E. (2013). The art of coaching: Effective strategies for school transformation. John Wiley \& Sons.

Barad, K. (2007). Meeting the universe halfway: Quantum physics and the entanglement of matter and meaning. Durham: Duke University Press.

Boldt, G. M. (2017). Working with Deleuze and Guattari in early childhood research and education. In L. E. Cohen \& S. Waite-Stupiansky (Eds.), Theories of early childhood education: developmental, behaviorist, and critical (pp. 180-189). New York: Routledge.

Coburn, C. E., \& Woulfin, S. L. (2012). Reading coaches and the relationship between policy and practice. Reading Research Quarterly, 47(1), 5-30. doi:10.1002/RRQ.008

Cormier, D. (2008). Rhizomatic education: Community as curriculum. Innovate: Journal of Online Education, 4(5). Retrieved April 14, 2019, from https://www.learntechlib.org/p/104239/

Costa, A. L., \& Garmston, R. J. (2002). Cognitive coaching: A foundation for renaissance schools (2nd ed.). Norwood, MA: Christopher-Gordon.

Cuban, L. (1998). How schools change reforms: Redefining reform success and failure. Teacher's College Record, 99(3), 453-477.

de Freitas, E. (2012). The classroom as rhizome: New strategies for diagramming knotted interactions. Qualitative Inquiry, 18(7), 557-570. doi: $10.1177 / 1077800412450155$ 
DeLanda, M. (2016). Assemblage theory. Edinburgh, UK: Edinburgh University Press.

Deleuze, G., \& Guattari, F. (1987). A thousand plateaus: Capitalism and schizophrenia. (B. Massumi, Trans.). Minneapolis, MN: University of Minnesota Press.

Deleuze, G., \& Parnet, C. (1987). Dialogues. (H. Tomlinson \& B. Habberjam, Trans.). New York: Columbia University Press.

Elish-Piper, L., \& L'Allier, S. K. (2011). Examining the relationship between literacy coaching and student reading gains in grades $\mathrm{K}-3$. The Elementary School Journal, 112(1), 83-106. doi:10.1086/660685

Freire, P. (1970/2002). Pedagogy of the oppressed. London, U.K.: Bloomsbury.

Goldenberg, C. (1992). Instructional conversations: Promoting comprehension through discussion. The Reading Teacher, 46(4), 316- 326.

Government Publishing Office (2006). Income eligibility guidelines. Federal Register, 71(50). Retrieved July 11, 2018, from https://www.gpo.gov/fdsys/pkg/FR-200603-15/pdf/06-2476.pdf

Hagood, M. (2004). A rhizomatic cartography of adolescents, popular culture, and construction of self. In K. Leander \& M. Sheehy (Eds.), Spacializing literacy research and practice (pp. 143-160). New York: Peter Lang.

Haneda, M., Sherman, B., \& Teemant, A. (2019). Assisted performance through instructional coaching: A critical sociocultural perspective. In M. Haneda \& Nassaji, H. (Eds.), Perspectives on language as action: Essays in honor of Merryl Swain. Bristol, UK: Multilingual Matters. 
Haneda, M., Teemant, A., \& Sherman, B. (2017). Instructional coaching through dialogic interaction: Helping a teacher to become agentive in her practice. Language and Education, 31(1), 46-64. doi:10.1080/09500782.2016.1230127

Hofsess, B. A., \& Sonenberg, J. L. (2013). Enter: Ho/rhizoanalysis. Cultural Studies $\leftrightarrow$ Critical Methodologies, 13(4), 299-308. doi:10.1177/1532708613487877

Knight, J. (2007). Instructional coaching: A partnership approach to improving instruction. Thousand Oaks, CA: Corwin.

Kopp, B. (2012). IPS students start program to combat bullying. WTHR. Retrieved August 22, 2018, from https://www.wthr.com/article/ips-students-start-programto-combat-bullying

Kraft, M. A., Blazar, D., \& Hogan, D. (2018). The effect of teacher coaching on instruction and achievement: A meta-analysis of the causal evidence. Review of Educational Research, 88(4), 547-588. doi:10.3102/0034654318759268

Kuby, C. R. (2017). Rhizomes and intra-activity with materials: Ways of disrupting and reimagining early literacy research, teaching, and learning. In J. M. Iorio \& W. Parnell (Eds.), Meaning making in early childhood research: Pedagogies and the personal (pp. 168-187). New York, NY: Routledge.

Latour, B. (2017). Facing Gaia. Eight lectures on the new climatic regime. (Cathy Porter, Trans.). Medford, MA: Polity Press.

Leander, K., \& Wells Rowe, D. (2006). Mapping literacy spaces in motion: A rhizomatic analysis of a classroom literacy performance. Reading Research Quarterly, 41(4), 428-460. doi:10.1598/RRQ.41.4.2 
Lewis, C., Enciso, P., \& Moje, E. B. (Eds.). (2007). Reframing sociocultural research on literacy: Identity, agency, and power. Mahwah, NJ: Lawrence Erlbaum Associates.

Lewison, M., Leland, C., \& Harste, J. C. (2014). Why do we need an instructional theory of critical literacy? In Creating critical classrooms : Reading and writing with an edge (pp. 1-23). New York, NY: Routledge. doi:10.4324/9781315817842

Livesey, G. (2010). Assemblage. In A. Parr (Ed.), Deleuze dictionary (revised ed.) (pp. 18-19). Edinburgh, UK: Edinburgh University Press.

Lorraine, T. (2010). Lines of Flight. In A. Parr (Ed.), Deleuze dictionary (revised ed.) (pp. 147-148). Edinburgh, UK: Edinburgh University Press.

Mackness, J., Bell, F., \& Funes, M. (2016). The rhizome: A problematic metaphor for teaching and learning in a MOOC. Australasian Journal of Educational Technology, 32(1). doi:10.14742/ajet.2486

National Center for Education Statistics (2012). Number and percentage of public school students eligible for free or reduced-price lunch, by state: Selected years, 2000-01 through 2010-11. Digest of Education Statistics. Retrieved July 11, 2018, from https://nces.ed.gov/programs/digest/d12/tables/dt12_046.asp

Parr, A. (2010). Deleuze dictionary (revised ed.). Edinburgh, UK: Edinburgh University Press.

Rainville, K. N., \& Jones, S. (2008). Situated identities: Power and positioning in the work of a literacy coach. The Reading Teacher, 61(6), 440-448. doi:10.1598/RT.61.6.1

Semetsky, I. (2006). Deleuze, education, and becoming. Boston, MA: Sense. 
Shidler, L. (2009). The Impact of Time Spent Coaching for Teacher Efficacy on Student Achievement. Early Childhood Education Journal, 36(5), 453-460. doi: $10.1007 / \mathrm{s} 10643-008-0298-4$

Stagoll, C. (2010). Becoming. In A. Parr (Ed.), Deleuze dictionary (revised ed.) (pp. 147148). Edinburgh, UK: Edinburgh University Press.

Strom, K. J. (2018). “That's not very Deleuzian”: Thoughts on interrupting the exclusionary nature of "High Theory." Educational Philosophy and Theory, 50(1), 104-113.

doi:10.1080/00131857.2017.1339340

Strom, K. J., \& Martin, A. D. (2017). Becoming-teacher: A rhizomatic look at first-year teaching. Rotterdam, The Netherlands: Sense.

Teemant, A. (2014). A mixed methods investigation of instructional coaching for teachers of diverse learners. Urban Education, 49(5), 574-604.

doi: $10.1177 / 0042085913481362$

Teemant, A. (2018). Sociocultural theory as everyday practice: The challenge of K-12 teacher preparation for multilingual and multicultural learners. In J. P. Lantolf, \& M. E. Poehner (Eds.) with M. Swain (pp. 529-550), The Routledge handbook of sociocultural theory and second language development. New York, NY: Routledge.

Teemant, A., Leland, C., \& Berghoff, B. (2014). Development and validation of a measure of Critical Stance for instructional coaching. Teaching and Teacher Education, 39, 136-147. doi:10.1016/j.tate.2013.11.008. 
Tharp, R., Estrada, P., Dalton, S., \& Yamauchi, L. A. (2000). Teaching transformed: Achieving excellence, fairness, inclusion, and harmony. Boulder, CO: Westview. Vossoughi, S., \& Gutierrez, K. (2016). Critical pedagogy and sociocultural theory. In I. Esmonde \& A. Booker (Eds.), Power and privilege in the learning sciences: Critical and sociocultural theories of learning (pp. 138-161). Abingdon, U.K.:

Taylor \& Francis.

Vygotsky, L. S. (1978). Mind in society: The development of higher psychological processes (M. Cole, V. John-Steiner, S. Scribner, \& E. Souberman, Eds.). Cambridge, MA: Harvard University Press.

\footnotetext{
${ }^{1}$ The structure of a coaching cycle noted here is used by other established coaching approaches (Costa \& Garmston, 2002; Knight, 2007).

${ }^{2}$ In the US context, to qualify for free/reduced lunch, a family must earn $130 \%$ to $185 \%$ of the federally determined poverty line. For a family of four in 2007, the required annual income for free lunch would have been $\$ 37,000$ or less (Government Publishing Office, 2018).
} 